Section Editor

Mitchell S.V. Elkind, MD, MS

Abhijit Das, MD, DM

Pranav D. Shinde, MD, $\mathrm{DM}$

Chandrasekharan

Kesavadas, MD

Muralidharan Nair,

MD, DM

Address correspondence and reprint requests to Dr. Abhijit Das, 1199 Pleasant Valley Way, West Orange, NJ 07052 abhijit.neuro@gmail.com

\section{Teaching NeuroImages: \\ Onion-skin pattern facial sensory loss}

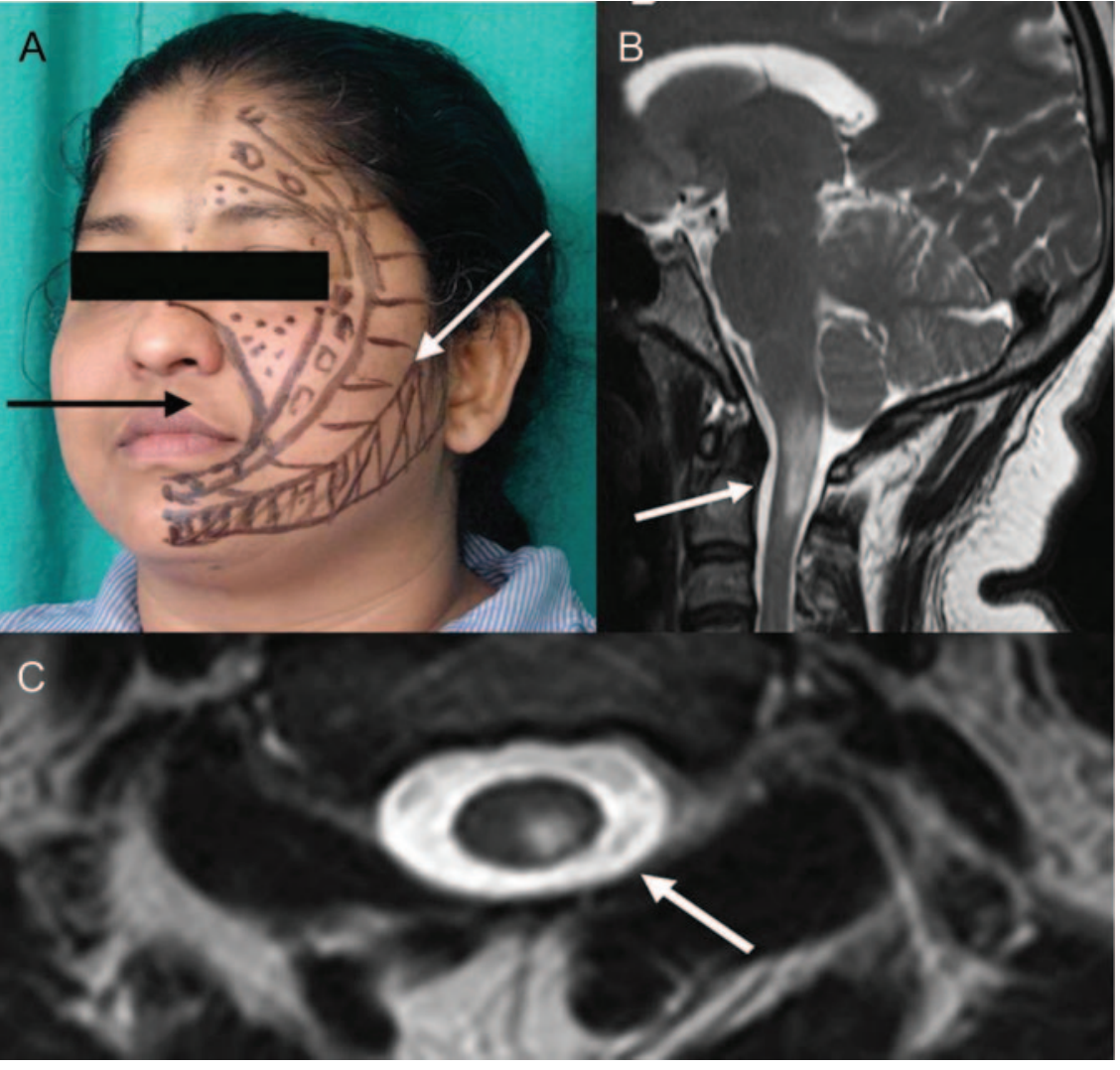

(A) Different patterns showing gradation of loss. White arrow, maximal loss peripherally; black arrow, spared central part of face. (B) Sagittal T2 MRI shows a hyperintense lesion in the brainstem and spinal cord extending from the lower medulla to C2 level. (C) Axial T2 MRI at the level of the upper cervical cord shows a hyperintense lesion in the left posterior-lateral cervical cord.

A 42-year-old woman presented with acute-onset facial numbness. Physical examination revealed graded loss of pain and temperature over the left half of her face with central sparing (figure 1A) —an onion-skin distribution. Corneal reflex was sluggish on the left, but results for the rest of the clinical examination, CSF studies, and visual evoked potential were normal. MRI was suggestive of acute demyelination (figure $1, \mathrm{~B}$ and $\mathrm{C}$ ), and the patient's condition improved with steroids. This segmental pattern of trigeminal sensory loss, in contrast to the divisional pattern (figure 2, A and B), reflects the rostral-caudal somatotopic arrangement in the spinal tract nucleus of the trigeminal nerve with the perioral area represented rostrally and the lateral face caudally (figure 2C) $)^{1,2}$ and helps in anatomic localization.

\section{REFERENCES}

1. Blumenfeld H. Neuroanatomy through Clinical Cases, 1 st ed. Sunderland, MA: Sinauer Associates; 2002.

2. Brazis PW, Masdeu JC, Biller J. Localization in Clinical Neurology, 5th ed. Philadelphia: Lippincott Williams \& Wilkins; 2007.

From the Departments of Neurology (A.D., P.D.S., M.N.) and Imaging Sciences and Interventional Radiology (C.K.), Sree Chitra Tirunal Institute for Medical Sciences and Technology, Trivandrum, India.

Disclosure: The authors report no disclosures. 
Figure 2 Divisional pattern of sensory loss (A), segmental pattern of sensory loss (B), and schematic diagram of the trigeminal system in the brainstem (C)

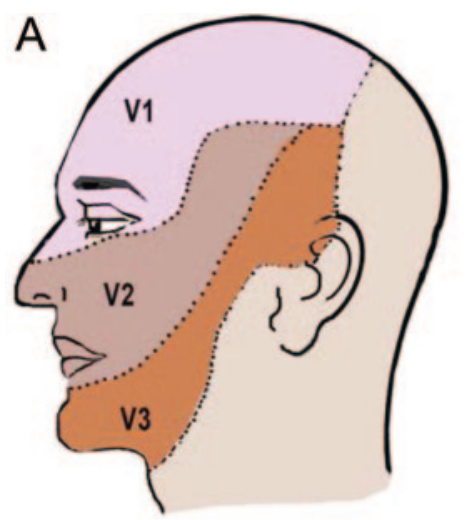

C

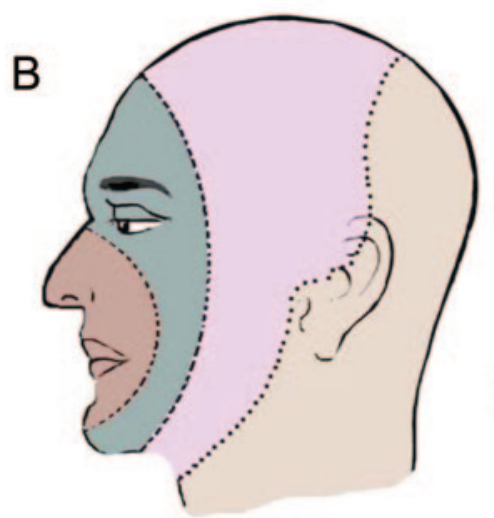

Midbrain

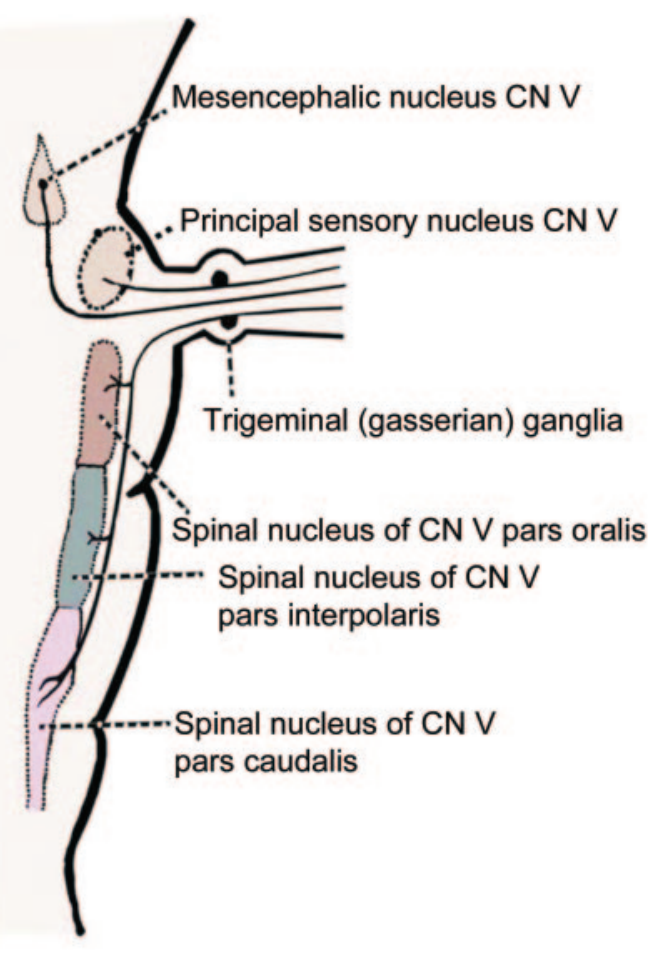

$\mathrm{CN}=$ cranial nerve. (A, B) Reprinted from Blumenfeld, ${ }^{1}$ with permission. (C) Reprinted from Brazis et al., ${ }^{2}$ with permission. 


\title{
Neurology
}

\author{
Teaching NeuroImages: Onion-skin pattern facial sensory loss \\ Abhijit Das, Pranav D. Shinde, Chandrasekharan Kesavadas, et al. \\ Neurology 2011;77;e45-e46 \\ DOI 10.1212/WNL.0b013e31822affc6
}

This information is current as of August 22, 2011

\section{Updated Information \& Services}

Subspecialty Collections

Permissions \& Licensing

Reprints including high resolution figures, can be found at:

http://n.neurology.org/content/77/8/e45.full

This article, along with others on similar topics, appears in the

following collection(s):

All Clinical Neurology

http://n.neurology.org/cgi/collection/all_clinical_neurology

All Demyelinating disease (CNS)

http://n.neurology.org/cgi/collection/all_demyelinating_disease_cns

\section{MRI}

http://n.neurology.org/cgi/collection/mri

Transverse myelitis

http://n.neurology.org/cgi/collection/transverse_myelitis

Information about reproducing this article in parts (figures,tables) or in its entirety can be found online at:

http://www.neurology.org/about/about_the_journal\#permissions

Information about ordering reprints can be found online:

http://n.neurology.org/subscribers/advertise

Neurology ${ }^{\circledR}$ is the official journal of the American Academy of Neurology. Published continuously since 1951, it is now a weekly with 48 issues per year. Copyright Copyright (? 2011 by AAN Enterprises, Inc.. All rights reserved. Print ISSN: 0028-3878. Online ISSN: 1526-632X.

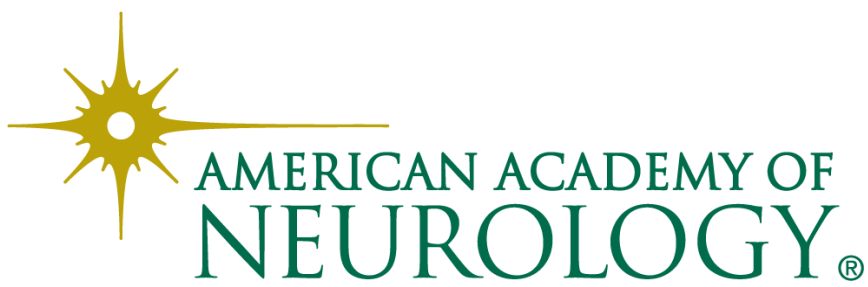

